DOI: 10.24193/OJMNE.2020.34.09

\title{
SHORT SUPPLY CHAINS FROM AN INTERMEDIARY'S POINT OF VIEW
}

\author{
Beáta Sz.G. PATÓ, PhD \\ University of Pannonia, Hungary \\ patog@,vnet.hu \\ Ágnes CSISZÁRIK-KOCSIR, PhD \\ Óbuda University, Hungary \\ kocsir.agnes@kgk.uni-obuda.hu \\ Imre VARGA, PhD \\ ELTE Savaria University Centre, Hungary \\ varga.imre@sek.elte.hu \\ Márk, HERCZEG, PhD candidate \\ University of Pannonia, Hungary \\ defiasser@hotmail.com \\ Ákos DOMINEK, PhD candidate \\ Óbuda University, Hungary \\ akos.dominek@gmail.com \\ Bálint PATÓ \\ Hungarian-English Bilingual Secondary Grammar School, Hungary \\ pato.balint@dlsb.hu \\ Fanni KISS \\ University of Pannonia, Hungary \\ kfanni0125@gmail.com
}

\begin{abstract}
In our increasingly globalized world, access to the right products and food is a central issue for all consumers. An alternative form of supply are local products, which can meet all or part of consumers' needs. These local products are local specialties and non-mass products, which are tied to local features, technologies, culture, and identity. Supply chains can also help to improve the viability and sustainability of producers. In order for these short supply chains to work well, there is a need for continuous feedback and evaluation, therefore supplier evaluation forms could act as the starting point of these chains. The supplier evaluation form can serve to support and develop these supply chains at the local level. The aim of this study is to present a short supply chain from an intermediary's point of view based on a case study. This method enables to gain a broader insight into the operation of local food chains. As the case study reveals, it is recommended for the members of these chains to apply supplier evaluation forms in order to maintain a better relationship between the partners. According to the experiences and conclusions a supplier evaluation system is defined by the authors.
\end{abstract}

Keywords local product, supplier evaluation, short supply chain, modelling.

\section{Introduction}

Local products and specialties can be purchased directly to consumers and/or via an intermediary as well. The aim of this study is to present a short supply chain from an intermediary's point of view on the basis of a case study performed. Operating in local food chains can foster 
viability in case of local products, when effective communication is maintened between the partners. Constant evaluation could be a key factor in case of well-operating supply chains, thus the application of supplier evaluation forms should be considered. The scientific relevance of this research is to draw particular attention to the realationship between the members of short supply chains and the importance of continous evaluation. Firstly the literature on the three most relevant topics are discussed: local products, short supply chains and supplier evaluation forms. The most important definitons, characteristics and current research findings are mentioned. In the second half of the article, the case study of an intermediary is summarized and the research questions are answered. Finally, in the suggestion section the supplier evaluation system - defined by the authors - is represented.

\section{Local products}

The 1970s were the milestone of globalization, when multinational companies expanded in fast speed and a global economic system was created. (Varga et al., 2019) In today's modern world, the role of local products is reappearing. There is a growing demand for healthier food, therefore many consumers are eager to buy local products. These are not only good to substitute different kinds of imports, but to serve as adequate nutrients. (Hoop and Jehlička, 2017; Szakály and Berke, 2004).

\section{Definition of local product}

In scientific literature, there is no universally applied definition of local food. The main characteristic is the geographical concept meaning the distance between local producers and consumers. Furthermore, the social and supply chain characteristics are important terms as well. Considering the geographical concept, a radius measure is determinated within which the local product is produced and sold. Distances may vary by country or even region, in some definitions a 100-mile radius is used, while in Hungary a $40 \mathrm{~km}$ radius is stated. Some production methods are also associated with local products, including reduced use of synthetic chemicals, environmentally-friendly production and sustainable production. The other concept is the short supply chain of local product, meaning that there is no, or only a limited number of intermediaries between the producer and the consumers. The social importance is that consumers are 'close' to 
producers, so they can create and maintain a good relationship with each other, therefore information reaches consumers through personal communication. (Martinez et al., 2010)

Table 1: The most common local products

\begin{tabular}{|l|l|}
\hline Agricultural products & Hand-made products \\
\hline $\begin{array}{l}\text { Products of vegetal origin (vegetables, } \\
\text { fruits) }\end{array}$ & Wooden products (barrel, furniture) \\
\hline Products of animal origin (egg, meat) & Products made from stone (furnace) \\
\hline Processed products (pastas, dairy products) & $\begin{array}{l}\text { Products made from iron (candlestick, } \\
\text { kettle) }\end{array}$ \\
\hline Bio products & Pottery and glass products \\
\hline & Textile products (lace, embroidery) \\
\hline & Braided product (baskets) \\
\hline
\end{tabular}

(Source: Own construction based on Eszterhai, 2014, pp.5-6)

Based on his review research, Csonka (2015) lists the six main characteristics of local products:

- $\quad$ geographical proximity of production and consumption,

- decline of the commercial sectors within the supply chain,

- contribution to sustainability and environmental protection,

- $\quad$ social embeddedness,

- dominance of small- and medium-sized enterprises,

- $\quad$ unique and special consumer value.

\section{$\underline{\text { Sale of local products }}$}

Local products can be produced and sold by primary producers, small producers, family farms, craftsmen, private entrepreneurs, businesses, cooperatives. Most of the products are sold locally, within a $40 \mathrm{~km}$ radius long circle. Local products are suitable for promoting the area and generating revenue for the region. The main feature of local products is that production, processing and sales are as close to each other as possible, and the product reaches the consumer directly or through a single intermediary, so the supply chain is short. Some typical forms of selling local 
products are the 'pick your own' actions, sale at infield, on the market, by roads, at different festivals and events, or to intermediaries. Nowadays, online sale is getting widespread as well, especially for hand-made local products. (Eszterhai, 2014) Horváth et al. (2019a) provide a short list of the most common places of sale in local products systems: roadside point of sale, home/yard of the farmer/producer, home delivery, producer's market, web store, pick yourself, guest table.

\section{Short supply chains}

Nowadays short supply chains are becoming increasingly popular among consumers, producers and non-governmental organizations. In North America and Western Europe short supply chains have multiple-decade-long history, and they are getting widespread in Hungary as well. Compared to the traditional mainstream models, short food supply chains provides something different. They are able to exploit local opportunities and resources, while being able to connect the producers with their consumers. (Chiffoleau et al., 2019) The competitiveness of the participants depend on their ability to work together, as it is much more efficient to compete as an entire supply chain. (Mesić et al., 2018) Short supply chains can be considered as sustainable strategies, providing a large variety of benefits for certain local areas. (Sachin et al., 2020). The sale of local products via short supply chains can contribute to the effective development of the countryside and to the creation of new workplaces. Furthermore, young adults are more likely to stay in their hometown. (Dajnoki et al., 2018) In work situations based on local values, stress and conflicts can be minimalised through similar norms and appropriate communication. (SzabóSzentgróti et al., 2019). It is also very important to emphasise the value added activities that these supply chains can provide, and also the flexibility and resilience of these supply chains, allowing them to react better to certain disruptive events. (Tukamuhabwa et al., 2017)

\section{Definition of short supply chains}

Several different definitions of short supply chains exist, but they are generally characterized by there being a minimal geographical and cultural distance between producers and consumers. According to the European Rural Development Regulation (1305/2013) a short supply chain is 'a supply chain involving a limited number of economic operators, committed to cooperation, local economic development, and close geographical and social relations between producers, processors and consumers'. This definition highlights the social relations and economic 
development as well. Ilbery and Maye (2005) state that:' the direct relationship between the producer and the consumer involves construction of knowledge, value and meaning about the product and it provenance, production and consumption, the producer and the consumer themselves, rather than solely an exchange of a product. These two authors focus on knowledge exchange besides social relations. According to Peters (2012) the criteria for short supply chains are the number of intermediaries and physical distance: 'short supply chains are not only focused on the distance between production and sale of product, but also the number of links in the food supply chain, with the goal being to reduce this as much as possible'. Summarizing the definitions, the most important criteria of short supply chains are: reduced number of intermediaries, physical proximity, importance of social relations and cooperation, and rural economic development.

Marsden et al. (2000) state, that in short food supply chains the most important characteristics are the role of relationship between partners and the value constructed by them. They also belive that it is more necessary that information about the products reach consumers, than the distance or number of intermediaries between partners. Information can be written on the package or said directly to customers at the point of sale. The application of short supply chains has economic, social and environmental advantages. The economic advantage means that money is spinning within the local community and there is a higher profit due to reduced transport costs. The social advantages are that producers can create a closer relationship with consumers and product details can be known better. The application of short supply chains has a reduced environmental impact from transport and storage due to smaller distances. (Benedek, 2014) From the above listed advantages of short supply chains the economic advantage is the most quantifiable by applying financial methods. The reduction of transport costs can be measured specifically, by which the company can earn a higher profit or by the reduction of final prices and the enhancement of quantity at the same time.

\section{Types of short supply chains}

There are several classifications for short supply chains, but the most widespread is the classification by Renting and his co-authors. Renting et al. (2003) defined three different types of short supply chains on the basis of physical distance and the number of intermediaries. The Faceto-face supply chain means that the local producer sells the product directly to the final customer without any intermediaries. The second type is the Proximate short supply chain in which one 
intermediary appears in the short supply chain (e.g. local shops, service providers, public institutions). In this context the sale of products is made locally, in a specific region. The third category is the Spatially extended short supply chain - products are sold not only locally but in different regions as well. In these chains consumers are usually not aware of the origin of the product and the region where it is coming from.

\section{Supplier evaluation}

The assessment of supply chains and their participants requires an extended knowledge about their environmental performance and aspects. Therefore, the evaluation and careful selection of certain suppliers are in fact anything but easy. (Tuni and Rentizelas, 2018) It is crucial to choose the adequate indicators and attributes of the suppliers in order to acquire reliable data, which is used for the evaluation. Without proper information, distorted results can be the outcome of the process, which can lead to false conclusions. (Clauß and Tangpong, 2019) Organizations that are able to manage suppliers efficiently, can be successful in the long-term. Application of supplier evaluation form can act as a starting point for that. Each organization has to decide whether they apply supplier evaluation or not. If they do, it is needed to define the main evaluation criteria which have to be in harmony with the organization's strategy. (Disselkamp, 2004) The supplier selection is a complicated process, which includes certain unpredictable factors, that may affect the outcome of the procedure. (Bilişik et al., 2012) The evaluation can improve the efficiency and performance of the supply chain, and can help the different participants improve the profitability and competitiveness. (Ashtarinezhad et al., 2018; Horváth et al., 2019b) The main factor of supplier relationships is the accurate and purposeful evaluation of suppliers. The aims of the application of supplier evaluation forms are the selection of the best supplier possible, the enhancement of suppliers' performance and controlling the relationship with suppliers (Vörösmarty and Tátrai, 2010). The purchase of local products should be supported, for which supplier evaluation can act as a basis, like advertisements or the application of local money as well. (Juhász and Varga, 2018)

\section{Types of supplier evaluation forms}

Szegedi and Prezenszki (2005) differentiate three distinct categories. The simple, categorical method is the simplest of them. The organization defines evaluation criteria to which the values are assigned. Usually, 3-7 value categories are applied in practice, in order to keep the 
method simple. On the other hand, there is no numerical data involved supporting the details, therefore categories should be regularly supervised to minimize subjectivity (Szegedi and Prezenszki, 2005). Figure 1 is an example for the simple, categorical method.

Figure 1: Sample for simple, categorical supplier evaluation

\begin{tabular}{|l|l|l|l|}
\hline Supplier Evaluation Form \\
\hline Name of supplier: \\
\hline Address of supplier: \\
\hline Code of supplier: \\
\hline Phone number: \\
\hline Date of supply: \\
\hline Name of supplied product: & \multicolumn{2}{|l|}{} \\
\hline Number of products: & Low & Adequate & Excellent \\
\hline Characteristics & & $\mathrm{X}$ & \\
\hline Price & & & $\mathrm{X}$ \\
\hline Number of defective products & & $\mathrm{X}$ & \\
\hline $\begin{array}{l}\text { Number of damaged products due to } \\
\text { transportation }\end{array}$ & & & $\mathrm{X}$ \\
\hline Accurcy of transportation & $\mathrm{X}$ & & \\
\hline Payment terms & & $\mathrm{X}$ & \\
\hline Safety of packaging & & \\
\hline
\end{tabular}

(Source: Szegedi and Prezenszki, 2005, p.93)

The second method is the Cost-based supplier performance evaluation in which costs are represented and examined in the ratio of prime costs. Ratios are determined on the basis of different cost categories and the performance of suppliers is compared based on these ratios. This method is advantegous because suppliers can be easily compared. On the other hand it requires a huge amount of information and time. The third category is the Complex evaluation/assessment procedures, to which several methods belong to. The common characteristic is the use of numerical data. In general, weighted factors are ordered to the most basic elements of procurement. This method is relatively easy to understand, but it is quite time-consuming. (Szegedi and Prezenszki, 2005)

\section{The case study of Gusto Delicate}

This section contains the aim and the method of this study, the introduction of Gusto Delicate and the answers to the research questions. 


\section{Description and method of research}

The main goal of this case study detailed below is to represent short supply chains from an intermediary's point of view. The characteristics of short supply chains and local products, the relationships between partners and supplier evaluation is discussed.

This study is an exploratory research, therefore there is no hypothesis.

The research questions are the following:

- What are the characteristics of short supply chains' local products from an intermediary's point of view?

- What are the characteristics of customer-supplier relationships in short supply chains?

- What are the characteristics of supplier evaluation in short supply chains?

The scientific relevance of this study is to draw particular attention to short supply chains, which significantly define the livelihood of local producers and customers as well. The aim is to represent the importance of effective short supply chains in local economies.

The intermediary of the case study is well-known in its region, it is important to represent a best practice from which other actors, especially intermediaries can collect ideas.

\section{The Gusto Delicate and its short supply chain}

Gusto Delicate (established in 2013) is a gastronomy shop and café selling premium quality products in Veszprém, Hungary. The mission of the organization is to popularize local products besides Hungarian and foreign ones. There is a wide range of products, approximately 3500 different ones such as beverages, chocolates, tea, coffee, pastas, jams and other specialities. The establishment of two other Gusto gastronomy shops in Tata and Györ reveals the successful operation of the brand.

Figure 2 represents the short supply chain of Gusto Delicate. 
Figure 2: The short supply chain of Gusto Delicate

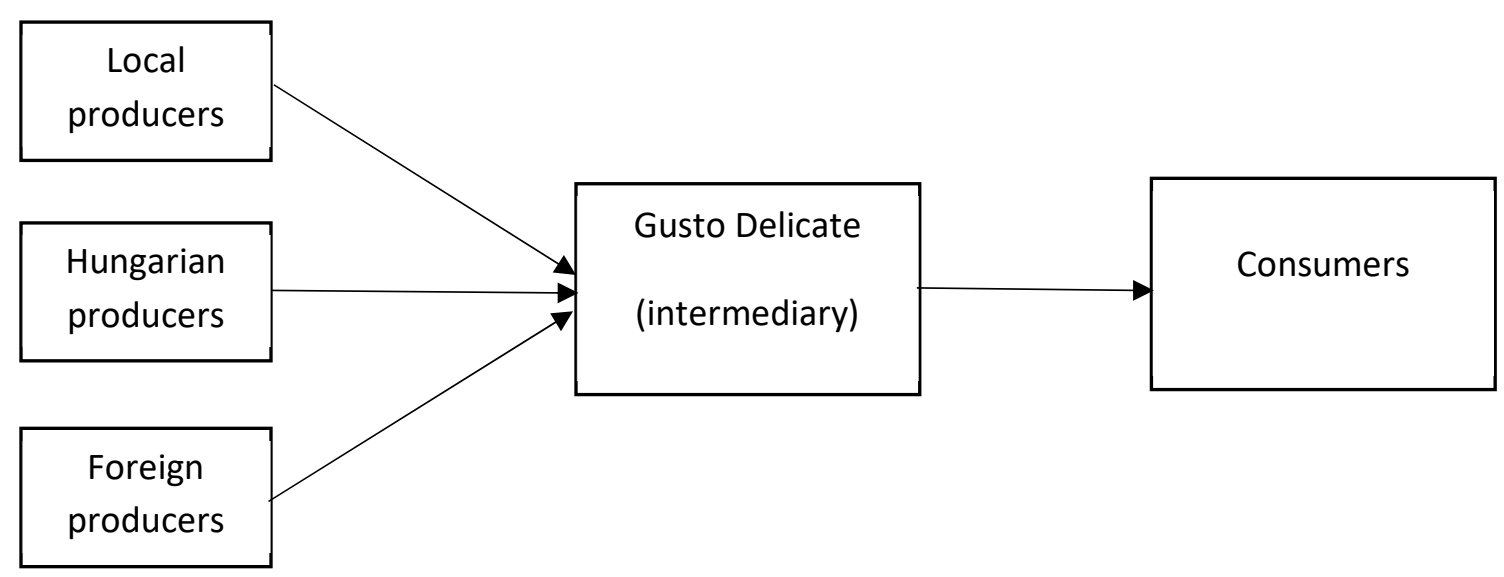

\section{(Source: Own construction)}

Supplier evaluation and customer-supplier relationship in case of Gusto

Gusto Delicate do not use formal, paper-based supplier evaluation form. Therefore, verbal communication and constant feedback between partners is of high importance. Emphasis is on mutual cooperation, because a successful partnership can provide several advantages for both sides. Local producers can target consumers through the intermediary, while Gusto can make a living by selling a huge number of products. The owner of Gusto Delicate defines some factors which have to be fulfilled by suppliers in case of a partnership. The organization finds it extremely important to constantly communicate with consumers, in order to get to know their opinions. Lesser known products have to be familiarized with consumers, for which the shop has a wellestablished strategy. This means a joint product display in cooperation with local producers in Gusto Delicate. This gives an opportunity for producers to present their products directly to consumers, which means personal contact. Customers can taste and share their opinions about the products. Certain products do not sell as well they should; in this case Gusto tries to find out the cause and solve the problem jointly with the producer. The above mentioned joint activities indicate that Gusto Delicate tries to maintain a mutually beneficial relationship with suppliers based on mutual trust and cooperation. The deatiled description of the most important factors which have to be fulfilled by suppliers are detailed below. 
1.Quality: It is one of the basic factors, because Gusto Delicate only merchandises premium quality goods, therefore outstanding and constant quality has to ensured. Consumers are questionned about their opinion on quality, and standards are based on those.

2.Price: Gusto Delicate applies markup pricing. It is hard to find a price which is accepted by the producer and is profitable for Gusto as well. At the beginning some producers set their prices too high, the same on which they sell their products to final consumers.

3.Packaging: Packaging has to protect the product and the environment as well. Besides that the logistical and the marketing function is of high importance too. In the retail industry, the marketing function of packaging is outstanding. Consumers pick up on the product with the help of the package and the labels. Packages also inform consumers about product details. In some cases, Gusto Delicate gave advice to producers to change their package. For example there was a high quality and tasteful biscuit packed in a limpid cellophane, which did not grab the attention of consumers. The sales manager of Gusto advised the local producer to redesign and change the packaging. The biscuits were packaged into a well-designed paper box, which resulted in the product selling five times as many as before. This example proves that cooperation between partners in short supply chains is beneficial for both sides, resulting in financial advantages.

4.Flexibility: Flexibility is important in case of quantity and transport as well. The suppliers of Gusto have to be able to react quickly to changing needs. Considering quantity, Gusto orders from suppliers based on demand. If certain products are sold in higher quantities, then they are ordered on a monthly bases, and are stored in Gusto's depot. During the holiday seasons (like Christmas or Easter), demand is naturally much higher. Due to some producers having smaller capacities, Gusto has to be flexible and order products in advance or help producers with transport.

5.Transport factors: The most basic factor of transport is reliability. Reliability means keeping the promises, such as on-time delivery in the right quality. Suppliers have to meet these requirements in order to maintain a partnership with Gusto. From some suppliers, who have a limited capacity for transport, the shop collects the products. Their suppliers meet these requirements.

Gusto Delicate is in cooperation with approximately 200 different suppliers including approximately 50 local producers in the region. The relationships with suppliers are characterized by trust and tight cooperation. Constant verbal communication and feedback resulted in wellworking partnerships. Gusto Delicate has to deal with several suppliers, therefore the application 
of formal supplier evaluation forms could be useful. The owner is open to the idea of testing a written supplier evaluation form.

\section{Suggestions}

The scientific literature suggests the application of supplier evaluation form. In the Gusto Delicate case study, feedback is made through verbal communication. However, the sales manager thinks it may be useful to apply a written evaluation form as well. Therefore, the authors created an innovative supplier evaluation form, which can be beneficial for all supply chain members. In the centre of the Double Evaluation Platform is the supplier who is evaluated from two 'aspects'. On the left side, the evaluation of the central organization is presented, while on the opposite side the consumers' evaluation can be seen.

Figure 3: The Double Evaluation Platform

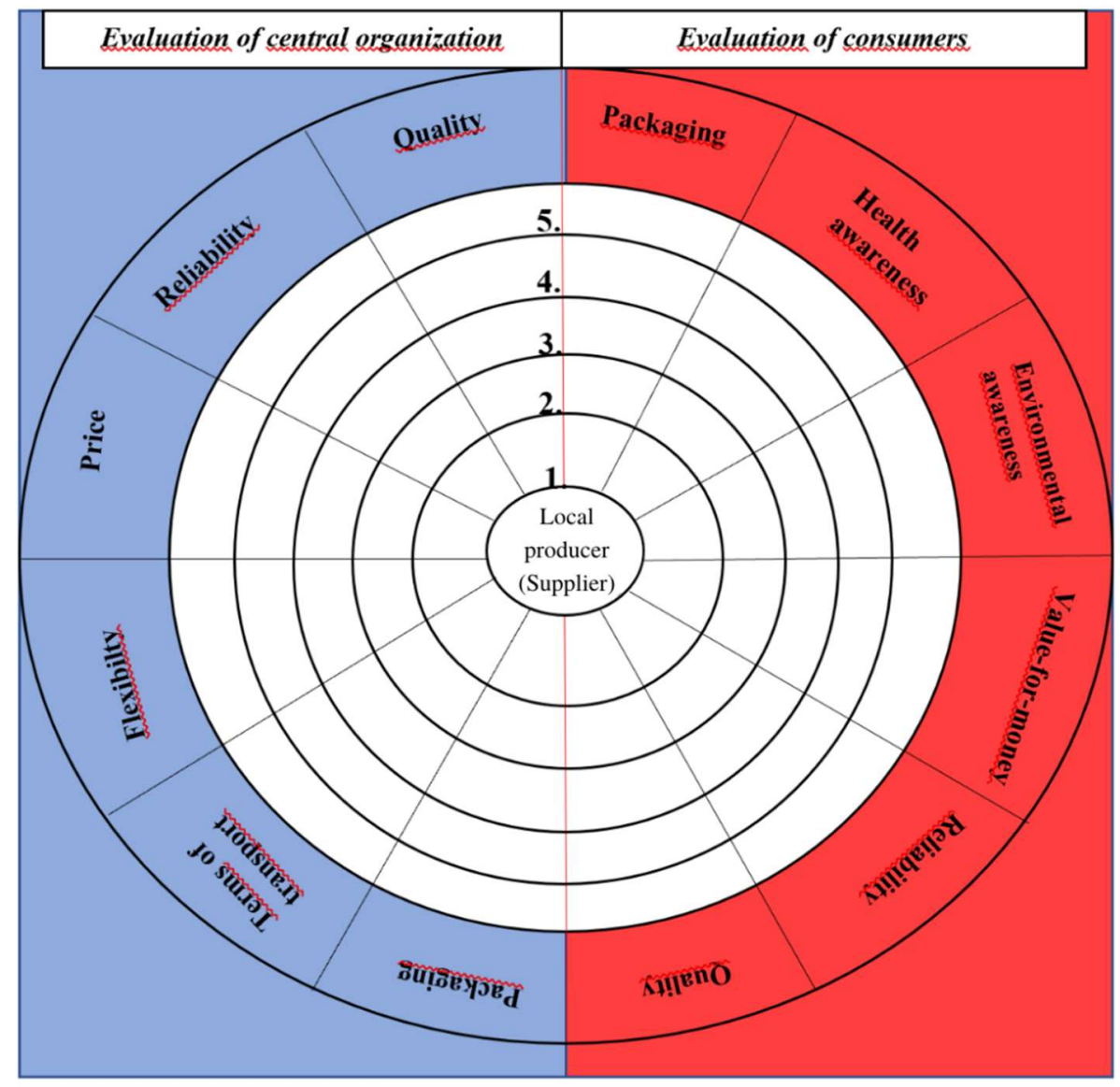

(Source: Own construction) 
The main advantage of the model is that two evaluations can be seen on the same platform. Both the producers and the central organization aim to satisfy consumer needs at the highest level possible, that is why consumer evaluation is just as important as supplier evaluation. In case of Gusto Delicate the left side of the model is filled in by the organization. The collection of consumers' opinions can be made for example at the joint product displays by questionnaires. By totalizing the consumer opinions, the right side of the model can be filled in.

The application of the model is beneficial for the central organization, because it can compare its ratings with consumers' evaluation. Furthermore, the relationship with customers can be improved while collecting opinions. For suppliers it is advantageous because they receive two different evaluations at the same time, thus the strengths and weaknesses can be seen. Suppliers can develop their activities based on the evaluations. With respect to consumers, their needs can be fulfilled better thanks to the application of the model.

The method of the model is based on the simple categorical method in which the evaluation factors and value categories have to be defined. Usually 5-10 evaluation factors and 3-7 value categories are common. The evaluation factors and value categories of Figure 3 is an example, the organization can form it according to their strategy. According to the example, 1 is for weak performance, 2 is acceptable, 3 means convenient, 4 is good and 5 is for excellent. When defining the evaluation factors on the consumers' side, the central organization and the suppliers should interact.

The selected value category is marked by $\mathrm{X}$ in the model in each evaluation factor. In the right side of the model, the aggregated value of consumers' opinions is represented. After the central organization and the consumers have assessed the evaluation factors, the weakness and strength of the supplier becomes visible.

\section{Conclusion}

Summarizing the case study, it can be stated that customer-supplier relationships in short supply chains are characterized by the collaborative model. It is proved by the case study that joint activities and co-working can be beneficial and profitable for both sides. In the short supply chains of local products, verbal supplier evaluation is widespread. However in case of intermediaries cooperating with several suppliers, it is advisable to apply a formal supplier evaluation form. 
Therefore the so-called Double Evaluation Platform was created by the authors to support the work of intermediaries.

In the center of the Double Evaluation Platform is the supplier who is evaluated from two 'aspects'. On the left side, the evaluation of the central organization is presented, while on the opposite side the consumers' evaluation can be seen. The conclusions are primarily based on the relevant scientific literature and the findings of the case study performed. Therefore, further research is planned to gain a broader insight into this topic. The future plan is to conduct a research with many intermediaries in order to get not only qualitative, but quantitative results as well. In addition, the testing of the Double Evaluation Platform in practical life is on the list as well.

\section{Author contribution}

Dr. Beáta Sz.G. PATÓ: Exploring the literature sources relevant to the research topic, conducting library research work for this; identification of topic-specific, relevant literature and processing of some literature sources - in the topic Short supply chains; Abstract; Introduction.

Dr. Ágnes Csiszárik-Kocsir: Exploring the literature sources relevant to the research topic, conducting library research work for this; identification of topic-specific, relevant literature and processing of some literature sources - in the topic Local products and Supplier evaluation.

Dr. Imre VARGA: Critical collision of the literature, collaboration of the processed literature into a coherent whole, finalization of the literature review.

Márk, HERCZEG and Ákos DOMINEK: Developing a list of structured questions in line with the research plan, identifying and designating the interviewee based on social capital, according to the research focus, and contact the interviewee, conducting the interview, recording information, preparing the case study with Gusto Delicate interviewee

Bálint, PATÓ and Fanni, KISS: Compilation of a draft case study and then writing of the case study based on the information gathered and recorded from the interviewee Gusto Delicate; Creation of The Double Evaluation Platform model, elaboration its conceptual scheme and the physical design and practical testing of the model; Conclusion

\section{References}

1. Benedek, Zs. (2014) A rövid ellátási láncok hatásai, Mühelytanulmány, MT-DP2014/8, MTA Közgazdasági és Regionális Kutatóintézet, pp.3-8, p.18, 
2. Bilişik, E. M., Çağlar, N. and Bilişik, A. N. (2012) A Comparative Performance Analyze Model and Supplier Positioning in Performance Maps for Supplier Selection and Evaluation, Procedia - Social and Behavioral Sciences, Volume 58, pp. 1434-1438, doi: 10.1016/j.sbspro.2012.09.1128

3. Clauß, T. and Tangpong, C. (2019) Perception-based supplier attributes and performance implications: a multimethod exploratory study, Journal of Supply Chain Management pp 7-11, https://doi.org/10.1111/jscm.12211

4. Chiffoleau, Y. and Millet-Amrani, S. - Rossi, A. - Rivera-Ferre, G.M. - Merino, L.P. (2019) The participatory construction of new economic models in short food supply chains, Journal of Rural Studies, Volume 68, pp. 1-5, https://doi.org/10.1016/j.jrurstud.2019.01.019

5. Csongrád, Magyarország: Agro-Assistance Kft., (2019) pp. 38-50.,

6. Csonka, A. (2015) „A helyi sertéshús ellátás gazdasági lehetőségei Magyarországon” [Economic possibilities of local pork supply chains in Hungary]. Élelmiszer, Táplálkozás és Marketing, Vol. 11 Issue:1-2. pp. 45-52.

7. Dajnoki, K., Szabados, Gy. and Kulcsár, G. - Bácsné, B. É. (2018) „Visszatérni vidékre" - A vidéki élet kvantitatív és kvalitatív megközelítésben. International Journal of Engineering and Management Sciences (IJEMS) Vol. 3. (2018). No. 5 DOI: 10.21791/IJEMS.2018.5.22.

8. Disselkamp, M. and Schüller, R. (2004) Lieferantenrating, Instrumente, Kriterien, Checklisten, Gabler Verlag is tein Unternehmen von Springer Science+Business Media, p 15

9. Elahe, A., Amir, H. S. and Mehrzad, N. (2018) Supplier evaluation and categorize with combine Fuzzy Dematel and Fuzzy Inference System, Data in Brief 18, pp. 1149-1151, https://doi.org/10.1016/j.dib.2018.03.077

10. Eszterhai, I. (2014) Helyi termék kézikönyv, Somogy Megyei Vállalkozói Központ Közalapítvány, Kaposvár, pp. 5-39.

11. European Parliament (2016) Short food supply chains and local food systems in the EU. Briefing, 2016 September

12. Hoop, de E. and Jehlička, P. (2017) Reluctant pioneers in the European periphery? Environmental activism, food consumption and "growing your own", Local Environment, 22:7, 811-818, DOI: 10.1080/13549839.2017.1289160 
13. Horváth, T., Csonka, A., Szerb, A. B. and Csima, F. (2019a) A minőség és a logisztikai költségek szerepe a cukorrépa beszerzésben. In: Bodnár, Károly (szerk.) 5. Logisztika a Dél-Alföldön: Lektorált tudományos konferenciakiadvány Csongrád, Magyarország: AgroAssistance Kft., (2019) pp. 38-50.

14. Horváth, T., Szerb, A. B. and Csonka, A. (2019b) Logisztikai kihívások a rövid élelmiszer láncokban. In: Bodnár, Károly (szerk.) 5. Logisztika a Dél-Alföldön: Lektorált tudományos konferenciakiadvány. Csongrád, Magyarország: Agro-Assistance Kft., (2019) pp. 3037.

15. Ilbery, B. and Maye, D. (2005) Alternative (shorter) food supplychains and specialist livestock productsin the Scottish-English borders, Environment and Planning, 37, pp. $823-844$

16. Juhász Z. and Varga I. (2018) A helyi pénz bevezetésnek főbb tapasztalatai Magyarországon. Vezetéstudomány 49:3 pp.19-27.

17. Marsden, T., Banks, J. and Bristow, G. (2000). Food supply chain approaches: Exploringtheir role in rural development. Sociologia Ruralis, 40(4), 424-438

18. Mesic. Ž., Molnár, A. and Cerjak, M. (2018), "Assessment of traditional food supply chain performance using triadic approach: the role of relationships quality", Supply Chain Management, Vol. 23 No. 5, pp. 396-411. https://doi.org/10.1108/SCM-10-2017-0336

19. Peters, R. (2012) Local Food and Short Supply Chains, EU Rural Review, N 12

20. Renting, H., Marsden, T.K. and Banks, J. (2003) Understanding of alternative food networks, exploring the role of short food supply chains in rural development, Environment and Planning, 35(3), pp.431-436

21. Sachin, S. K., Angappa, G. and Shradha, A. G. (2020) Achieving sustainable performance in a data-driven agriculture supply chain: A review for research and applications, International Journal of Production Economics Volume 219, January 2020, pp 179-184, https://doi.org/10.1016/j.ijpe.2019.05.022

22. Szabó-Szentgróti G., Gelencsér M., Szabó-Szentgróti E. and Berke, Sz. (2019) Generációs hatás a munkahelyi konfliktusokban. Vezetéstudomány - Budapest Management Review, 50 (4). pp. 77-88. DOI https://doi.org/10.14267/VEZTUD.2019.04.08 
23. Szakály Z. and Berke Sz. (2004) A táplálkozás, a minőség és a marketing kapcsolata élelmiszereknél, In: Berács, J; Lehota, J; Piskóti, I; Rekettye, G (szerk.) Marketingelmélet a gyakorlatban, KJK-KERSZÖV Jogi és Üzleti Kiadó Kft. (2004) pp. 319-335.

24. Szegedi, Z. and Prezenszki, J. (2005) Logisztika menedzsment, Kossuth Kiadó, Budapest, p.92-96

25. Tukamuhabwa, B., Stevenson, M. and Busby, J. (2017) "Supply chain resilience in a developing country context: a case study on the interconnectedness of threats, strategies and outcomes", Supply Chain Management: An International Journal, Vol. 22 Issue: 6, pp. 486-490, https://doi.org/10.1108/SCM-02-2017-0059

26. Tuni, A and Rentizelas, A. (2018) An innovative eco-intensity based method for assessing extended supply chain environmental sustainability, International Journal of Production Economics 217, pp.2-7 DOI: 10.1016/j.ijpe.2018.08.028

27. Varga, J. and Csiszárik-Kocsir, Á. (2019) Redefeining the Role of Project Leader for Achieving a Better Project Result, PM World Journal, Vol VIII, Issue VIII-September, pp.118

28. Vörösmarty, Gy. and Tátrai, T. (2010) Beszerzés, Stratégia, folyamatok, információ, Complex Kiadó Jogi és Üzleti Tartalomszolgáltató Kft., Budapest, p.38 